\title{
Systems metabolic engineering, industrial biotechnology and microbial cell factories
}

\author{
Sang Yup Lee ${ }^{1}$, Diethard Mattanovich 2,3 and Antonio Villaverde ${ }^{4,5,6^{*}}$
}

Cell factories have been largely exploited for the controlled production of substances of interest for food, pharma and biotech industries. Although human-controlled microbial production and transformation are much older, the cell factory concept was fully established in the 80's through the intensive public and private investment. Strongly empowered by the then nascent recombinant DNA technologies and supported by the approval of recombinant insulin [1,2], the principle of controlled biological production as a convenient source of difficult-to-obtain molecules (especially those of high added value) deeply penetrated the industrial tissue, soon becoming a widespread platform aiming at costeffective large-scale production [3]. The first generation cell factories (mainly composed by plain strains of the bacterium Escherichia coli and the yeast Saccharomyces cerevisae) were soon replaced by engineered variants. Resulting from the application of untargeted mutagenesis and phenotypic selection, conventional genetic modification, metabolic engineering, and more recently by systems metabolic engineering that integrates metabolic engineering with systems biology and synthetic biology, new strains having much enhanced performance have been progressively developed [4-19]. In parallel, mammalian and insect cells for the production of high quality proteins, and other microbial species appealing from an industrial point of view due to their unusual physiological traits, have been incorporated to the cell factory family $[20,21]$. This comprises algae, fungi, psychrophilic bacteria and moss, among others [22-26]. On the other hand, a set of food-grade lactic acid bacteria are under development as emerging platforms in food microbiology but also as a novel source of metabolites and proteins [27-34]. The physiological diversity of the microbial world offers an intricacy of biosynthetic

\footnotetext{
*Correspondence: antoni.villaverde@uab.cat

${ }^{4}$ Institut de Biotecnologia i de Biomedicina, Universitat Autònoma de Barcelona, Bellaterra, Barcelona 08193, Spain

${ }^{5}$ Department de Genètica i de Microbiologia, Universitat Autònoma de Barcelona, Bellaterra, Barcelona 08193, Spain

Full list of author information is available at the end of the article
}

pathways from which novel bio-products, including nano- or micro-structured materials [35-37], offer promises in even more diverse applications.

Still, many substances and materials of industrial interest are nowadays produced by chemical synthesis, and the number of (recombinant) proteins approved for therapeutic use hardly reaches 200 , a figure much lower than that initially presumed. However, both environmental concerns and medical and industrial needs strongly push towards a fully sustainable bio-production of a larger spectrum of substances. Then, how much limited is the economic feasibility of microbial production? Have the cell factories reached a plateau in their development? Is there more room for further exploitation of the microbial production?

Systems metabolic engineering [38,39] offers a set of methodological and strategic tools for the design and optimization of metabolic and gene regulatory networks for the efficient production of chemicals (from pharmaceuticals to bulk chemicals and fuels) and materials (from plastics to high value materials) [5-7,40]. Furthermore, creation of new metabolic pathways and fine tuning of the existing ones have become possible $[8,15]$. This is already allowing the production of substances so far reluctant to microbial production under industrial requirements and under cost-effective processes, allowing us to overcome limitations of microbial cell factories. In silico genome-scale metabolic modeling and simulation are playing increasingly important roles in systemwide identification of target genes and pathways to be manipulated to enhance production of desired products. Profiling of transcriptome, proteome, metabolome, and/ or fluxome is also becoming a routine practice in metabolic engineering for the better understanding of cellular characteristics under given genetic and/or environmental perturbations. Through the system-wide optimized design and development of microbial cell factories, many industrially important chemicals and materials could be efficiently produced. Some example products include, but not limited to, alcohols other than ethanol including 
propanol, butanol and isobutanol, dicarboxylic acids such as succinic acid, fumaric acid, malic acid and adipic acid, diols such as 1,3-propanediol, 1,2-propanediol, 1,4-butanediol and 2,3-butanediol, diamines such as putrescine and cadaverine, and even polymers including polyhydroxyalkanoates, polylactic acid, spider silk protein, poly-gamma-glutamic acid, and many others [40]. It is expected that increasingly diverse chemicals and materials that are currently produced by petrochemical industry will be produced by employing microbial cell factories.

Improving cell factories by systems biotechnology to an industrially relevant level cannot be successfully reached by individual teams alone. A wide range of expertise is needed for the full development of a novel biotechnological process, including microbiology, chemistry, bioinformatics, biochemical engineering, but also agricultural and plant sciences and economics. After a proof of concept has shown the feasibility of a novel approach for cell factory engineering, large consortia or networks of fully skilled teams should take over in collaboration with Biotech companies to accomplish an economically feasible bioprocess. As an early example, the development of bacteria producing 1,3-propanediol from glucose has been well documented, and required the engineering of more than 70 genes, before process development and scale up were reasonably made [41]. Replacing materials which are produced from mineral oil by biobased products requires not only efficient technology but also the assessment of economical and ecological feasibility, as intensely studied for polylactic acid [42].

As the progress of industrial biotechnology did not accomplish the desired speed of development [43] academic researchers have teamed up with industry in publicly funded research centers worldwide. To name a few, the Joint BioEnergy Institute (JBEI) in the San Francisco Bay Area, the Novo Nordisk Foundation Center for Biosustainability (CFB) at the Technical University of Denmark, the Metabolic and Biomolecular Engineering Laboratory (MBEL) of the Korea Advanced Institute of Science and Technology (KAIST), the Dutch Klyuver Centre for Genomics of Industrial Fermentation, or the Austrian Centre of Industrial Biotechnology (ACIB) share the mission to speed up development of industrial bioprocesses by joining forces of different academic disciplines with industrial collaborators.

\footnotetext{
Author details

${ }^{1}$ Metabolic and Biomolecular Engineering National Research Laboratory, Department of Chemical and Biomolecular Engineering (BK21 program), BioProcess Engineering Research Center, and Center for Systems and Synthetic Biotechnology, Institute for the BioCentury, KAIST, 291 Daehak-ro, Yuseong-gu, Daejeon 305-701, Republic of Korea. ²Department of Biotechnology, University of Natural Resources and Life Sciences (BOKU), Muthgasse 18, Vienna 1190, Austria. ${ }^{3}$ Austrian Centre of Industrial
}

Biotechnology (ACIB), Vienna, Austria. ${ }^{4}$ Institut de Biotecnologia i de Biomedicina, Universitat Autònoma de Barcelona, Bellaterra, Barcelona 08193, Spain. ${ }^{5}$ Department de Genètica i de Microbiologia, Universitat Autònoma de Barcelona, Bellaterra, Barcelona 08193, Spain. ${ }^{6} \mathrm{CIBER}$ de Bioingeniería,

Biomateriales y Nanomedicina (CIBER-BBN), Bellaterra, Barcelona 08193, Spain.

Received: 8 December 2012 Accepted: 9 December 2012

Published: 11 December 2012

\section{Reference}

1. ANONIMOUS: Human insulin receives FDA approval. FDA Drug Bull 1982 12:18-19.

2. Johnson IS: Human insulin from recombinant DNA technology. Science 1983, 219:632-637.

3. Marston FA: The purification of eukaryotic polypeptides synthesized in escherichia coli. Biochem J 1986, 240:1-12.

4. Makino T, Skretas G, Georgiou G: Strain engineering for improved expression of recombinant proteins in bacteria. Microb Cell Fact 2011, $10: 32$

5. Lee SY, Lee DY, Kim TY: Systems biotechnology for strain improvement. Trends Biotechnol 2005, 23:349-358.

6. Park JH, Lee SY, Kim TY, Kim HU: Application of systems biology for bioprocess development. Trends Biotechnol 2008, 26:404-412.

7. Lee SY, Kim HU, Park JH, Park JM, Kim TY: Metabolic engineering of microorganisms: general strategies and drug production. Drug Discov Today 2009, 14:78-88.

8. Na D, Kim TY, Lee SY: Construction and optimization of synthetic pathways in metabolic engineering. Curr Opin Microbiol 2010, 13:363-370.

9. Lee JW, Kim TY, Jang YS, Choi S, Lee SY: Systems metabolic engineering for chemicals and materials. Trends Biotechnol 2011, 29:370-378.

10. Adrio JL, Demain AL: Genetic improvement of processes yielding microbial products. FEMS Microbiol Rev 2006, 30:187-214

11. Demain $\mathrm{AL}$, Adrio JL: Strain improvement for production of pharmaceuticals and other microbial metabolites by fermentation. Prog Drug Res 2008, 65:251. 253-251, 289.

12. Adrio $J$, Demain $A L$ : Recombinant organisms for production of industrial products. Bioeng Bugs 2010, 1:116-131.

13. Demain $A L$, Adrio $\mathrm{J}$ : Essential role of genetics in the advancement of biotechnology. Methods Mol Biol 2012, 898:1-40.

14. Chen Z, Wilmanns M, Zeng AP: Structural synthetic biotechnology: from molecular structure to predictable design for industrial strain development. Trends Biotechnol 2010, 28:534-542.

15. Kondo A, Ishii J, Hara KY, Hasunuma T, Matsuda F: Development of microbial cell factories for bio-refinery through synthetic bioengineering. J Biotechnol 2012, [Epub ahead of print].

16. Lee $\mathrm{JH}$, Sung $\mathrm{BH}$, Kim MS, Blattner FR, Yoon BH, Kim JH, et al: Metabolic engineering of a reduced-genome strain of escherichia coli for L-threonine production. Microb Cell Fact 2009, 8:2.

17. Ferndahl C, Bonander N, Logez C, Wagner R, Gustafsson L, Larsson C, et al: Increasing cell biomass in saccharomyces cerevisiae increases recombinant protein yield: the use of a respiratory strain as a microbial cell factory. Microb Cell Fact 2010, 9:47.

18. Hasunuma T, Sanda T, Yamada R, Yoshimura K, Ishii J, Kondo A: Metabolic pathway engineering based on metabolomics confers acetic and formic acid tolerance to a recombinant xylose-fermenting strain of saccharomyces cerevisiae. Microb Cell Fact 2011, 10:2.

19. Krainer FW, Dietzsch C, Hajek T, Herwig C, Spadiut O, Glieder A: Recombinant protein expression in pichia pastoris strains with an engineered methanol utilization pathway. Microb Cell Fact 2012, 11:22.

20. Ferrer-Miralles N, Domingo-Espin J, Corchero JL, Vazquez E, Villaverde A: Microbial factories for recombinant pharmaceuticals. Microb Cell Fact 2009, 8:17

21. Gasser B, Saloheimo M, Rinas U, Dragosits M, Rodriguez-Carmona E, Baumann $\mathrm{K}$, et al: Protein folding and conformational stress in microbial cells producing recombinant proteins: a host comparative overview. Microb Cell Fact 2008, 7:11.

22. Corchero JL, Gasser B, Resina D, Smith W, Parrilli E, Vazquez F, et al: Unconventional microbial systems for the cost-efficient production of high-quality protein therapeutics. Biotechnol Adv 2012, S0734-9750(12) 00151-6. doi:10.1016/j.biotechadv.2012.09.001. 
23. Gong $Y, H u H$, Gao $Y, X u X$, Gao H: Microalgae as platforms for production of recombinant proteins and valuable compounds: progress and prospects. J Ind Microbiol Biotechnol 2011 ,

24. Hempel F, Bozarth AS, Lindenkamp N, Klingl A, Zauner S, Linne U, et al: Microalgae as bioreactors for bioplastic production. Microb Cell Fact 2011, 10:81.

25. Meyer V, Wu B, Ram AF: Aspergillus as a multi-purpose cell factory: current status and perspectives. Biotechnol Lett 2011, 33:469-476.

26. Spadiut O, Olsson L, Brumer III H: A comparative summary of expression systems for the recombinant production of galactose oxidase. Microb Cell Fact 2010, 9:68.

27. Le LY, Azevedo V, Oliveira SC, Freitas DA, Miyoshi A, Bermudez-Humaran LG, et al: Protein secretion in lactococcus lactis: an efficient way to increase the overall heterologous protein production. Microb Cell Fact 2005, 4:2.

28. Morello E, Bermudez-Humaran LG, Llull D, Sole V, Miraglio N, Langella P, et al: Lactococcus lactis, an efficient cell factory for recombinant protein production and secretion. J Mol Microbiol Biotechnol 2008, 14:48-58.

29. Peterbauer C, Maischberger T, Haltrich D: Food-grade gene expression in lactic acid bacteria. Biotechnol J 2011, 6:1147-1161.

30. Hu S, Kong J, Sun Z, Han L, Kong W, Yang P: Heterologous protein display on the cell surface of lactic acid bacteria mediated by the S-layer protein. Microb Cell Fact 2011, 10:86.

31. De Vos WM: Systems solutions by lactic acid bacteria: from paradigms to practice. Microb Cell Fact 2011, 10(1):S2.

32. Teusink B, Bachmann H, Molenaar D: Systems biology of lactic acid bacteria: a critical review. Microb Cell Fact 2011, 10(1):S11.

33. Rhee SJ, Lee JE, Lee CH: Importance of lactic acid bacteria in asian fermented foods. Microb Cell Fact 2011, 10(1):S5

34. Siezen RJ, Van HV: Genomic diversity and versatility of lactobacillus plantarum, a natural metabolic engineer. Microb Cell Fact 2011, 10(1):S3.

35. Rodriguez-Carmona E, Villaverde A: Nanostructured bacterial materials for innovative medicines. Trends Microbiol 2010, 18:423-430.

36. Villaverde A: Nanotechnology, bionanotechnology and microbial cell factories. Microb Cell Fact 2010, 9:53.

37. Vazquez E, Villaverde A: Engineering building blocks for self-assembling protein nanoparticles. Microb Cell Fact 2010, 9:101.

38. Lee KH, Park JH, Kim TY, Kim HU, Lee SY: Systems metabolic engineering of escherichia coli for L-threonine production. Mol Syst Biol 2007, 3:149.

39. Wittmann C, Lee SY (Eds): Systems metabolic engineering. Heidelberg, Germany: Springer; 2012. ISBN 978-94-007-4533-9.

40. Lee JW, Na D, Park JM, Lee J, Choi S, Lee SY: Systems metabolic engineering of microorganisms for natural and non-natural chemicals. Nat Chem Biol 2012, 8:536-546.

41. Liu H, Xu Y, Zheng Z, Liu D: 1,3-Propanediol and its copolymers: research, development and industrialization. Biotechnol J 2010, 5:1137-1148.

42. Vink ETH, Glassner DA, Olstad JJWROR: The eco-profiles for current and near-future nature works polylactide (PLA) production. Ind Biotechnol 2007, 3:58-81.

43. Chen GQ: New challenges and opportunities for industrial biotechnology. Microb Cell Fact 2012, 11:111.

doi:10.1186/1475-2859-11-156

Cite this article as: Lee et al:: Systems metabolic engineering, industrial biotechnology and microbial cell factories. Microbial Cell Factories 2012 11:156.

\section{Submit your next manuscript to BioMed Central and take full advantage of:}

- Convenient online submission

- Thorough peer review

- No space constraints or color figure charges

- Immediate publication on acceptance

- Inclusion in PubMed, CAS, Scopus and Google Scholar

- Research which is freely available for redistribution 